\title{
Knowledge and Attitude Towards Covid 19 Among Indian Residents: A Cross-Sectional Study
}

\section{Manisha Praharaj ${ }^{1}$, Kshirabdhi Tanaya ${ }^{1}$, Saurjya Ranjan Das ${ }^{2}$}

Section: Healthcare

Sci. Journal Impact

Factor: 6.1 (2018)

ICV: 90.90 (2018)

(c) (i) (8)

Copyright@IJCRR
'MSc. Tutor, SUM Nursing College, Siksha 'o' Anusandhan (Deemed to be University), Bhubneswar 751003, Odisha, India; ${ }^{2}$ Associate professor, Department of Anatomy, IMS \& SUM Hospital, Siksha 'o' Anusandhan (Deemed to be University), Bhubneswar 751003, Odisha, India.

\section{ABSTRACT}

Background: The 2019 coronavirus outbreak has caused a global health epidemic which changed the way we view our environment and our daily lives. The rate of transmission challenged our sense of identity and for safety and to prevent the spread of infection also need social distancing.

Objectives: The survey aimed to assess the knowledge \& attitude on coronavirus infection among the general population.

Methods: A total of 620 participants from Odisha urban community agreed to participate in the survey regarding COVID-19. A self-structured questionnaire was used to collect data. Participants were selected by convenient sampling method. The demographic characteristics were represented by frequencies and percentage. Descriptive statistics used to calculate mean, SD and P-value.

Results: Among the participants ( $n=620$ ), most of the participants $75.9 \%$ were females, more than half $59.4 \%$ of participants were between 31 to 40 years, majority $75.1 \%$ were living in the nuclear family, the majority $76.4 \%$ participants were married and a majority $75.9 \%$ were completed graduation. $80.28 \%$ of participants have good knowledge, $58.03 \%$ of participant's attitude was positive. Most of $72.6 \%$ participants believe India can win the battle against COVID 19, 85.1\% reported that their daily routine changed due to the pandemic.

Conclusion: The emerging coronavirus disease outbreak demands all people should maintain a minimum of 1-meter distance from each other and different various methods to ensure the safety of general people. There is a need for active public awareness, clear information, and strict guidelines to improve the knowledge and attitude of the general population.

Key Words: Covid-19, Knowledge, Attitude, Cross-sectional Study

\section{INTRODUCTION}

The coronavirus is a newfound infection which began in the live animal market of Wuhan, China on $12^{\text {th }}$ December 2019. It starts as an animal-to-person transmission and then the virus spread outside of Wuhan and then spread to the whole world by human contacts and it became the world's pandemic issue. ${ }^{1}$ Globally millions of lives have been changed drastically due to this deadly virus. The WHO declared it's a pandemic disease on $11^{\text {th }}$ of March, 2020. ${ }^{2}$ This newly found virus from the coronavirus family is more dangerous and unique due to its rapid transmissibility and less pathogenicity than the other virus of the same group like SARS - CoV $\&$ MERS-CoV. The govt. and the general population affected very much due to its rapid spreading and because it's fatal.
It has been a significant danger to people since December $31,2019 .{ }^{3,4}$ The infection is rising day by day and has killed many people. The infection spread so quickly that, after more than four months of $1^{\text {st }}$ infection the mortality and infection rate are increasing day by day and this infection turns out to be a major public health issue worldwide. ${ }^{5}$

Till the date there are 3.88 million confirmed cases and 271 thousand deaths worldwide, in India, there are 56, 342 confirmed cases and 1,886 deaths and in Odisha, there are 271 confirmed cases and two deaths. ${ }^{6}$ Till date there are no specific antiviral agents or vaccines, so the only way to reduce the infection is prevention. It appears that the latest widespread epidemic was caused may be due to late diagnosis and inadequate measures for managing infections. ${ }^{7,8}$ As transmission rate is very high, so having adequate knowledge, basic hy-

\section{Corresponding Author:}

Manisha Praharaj, MSc. Tutor, SUM Nursing College, Siksha 'o' Anusandhan (Deemed to be University), Bhubneswar 751003, Odisha, India; Email: manishapraharaj21486@gmail.com

ISSN: 2231-2196 (Print)

Received: 26.07 .2020
ISSN: $0975-5241$ (Online)

Revised: 09.10 .2020
Accepted: 27.10 .2020
Published: 14.12 .2020 
giene practice, good understanding, and enough information about sources, symptoms and modes of transmission have vital importance to reduce the spread of infection. Health authorities and Govt. of India have made significant efforts to control the spread of infection by various measures such as public education, public health awareness. ${ }^{9-10}$ This survey aimed to assess the knowledge and attitude of COVID 19.

\section{MATERIALS AND METHODS}

\section{Research design and sampling}

A cross-sectional survey was used to collect data from study subjects by using a self-structured questionnaire. In the present study, there are 620 participants from different urban community areas of Bhubneswar, Odisha. The date was collected by using a convenient sampling technique. People, who were aged 20 years or above with Indian nationality, who can read and understood the content and questionnaire, and gave their consent to participate had included in the present survey.

\section{Data collection}

The present study was conducted from April $15^{\text {th }}$ to $30^{\text {th }} 2020$. The data was collected during the lockdown period that is why it was not feasible for the author to collect data by face to face interview, so we collected the data online. The participants were given an introduction of the author, purpose of study, procedures to fill the answers, the confidentiality of participants and questionnaire was posted in WhatsApp group and mail. The participants were requested to respond to the entire questionnaire by selecting only one response. A self-structured questionnaire was formed based on attitude and knowledge of coronavirus. The questionnaire has three parts: demographic data, knowledge and attitude-based questions. The demographic data contains age, gender, education, occupation, types of family and marital status. Fifteen knowledge questionnaires were formed based on coronavirus. Each question has three options i.e. yes/no/maybe. For each correct response, one point and incorrect response zero points were assigned. The total range of knowledge score was 0 to 15 . Score range between 0 to 5 denoted as poor knowledge, 6 to 10 score denoted as average knowledge and 11 to 15 score denoted as good knowledge. Ten attitudebased questionnaires also formed and author assessed positive attitude and negative attitude based on the participants' response. The attitude was marked by three-point scales i.e. agree, disagree and neutral. In positive-attitude questions three points were given for agree responses, two points were given for neutral response and one point given for disagrees. In negative-attitude questions one point for agree response, three points for disagreeing. If the score is more than 20 it was considered a positive attitude, the score is 19- 10 it was considered as neutral and score less than 10 were considered as a negative attitude.
The collected data were coded and entered into excel sheet. Descriptive statistics were used to calculate frequency and percentage, mean, SD and P-value of demographic characteristics, knowledge and attitude.

\section{RESULTS}

In the present study, there were a total of 620 participants. Among them most of the participants (75.9\%) were females, more than half $(59.4 \%)$ of participants were between 31 to 40 years, the majority $(75.1 \%)$ were living in the nuclear family, the majority (76.4\%) participants were married, a majority $(75.9 \%)$ were completed graduation, and fewer participants $(24.9 \%)$ were doing the job.

Table 1 shows that the correct response of 15 knowledge questionnaire on COVID-19 was 56.8-92.7\%. The minimum of $52.3 \%$ participants responded correctly on the question the coronavirus is not related to SARS/MERS. All most all i.e. $92.7 \%$ participants responded correctly on question Isolation and treatment of infected people can reduce the spared of infection.

Figure 1 reveals a maximum $80.28 \%$ of participants had good knowledge of COVID 19 and very less i.e. only $4.4 \%$ of participants had poor knowledge.

Table 2 shows that mean and SD of knowledge score on COVID-19 was mean= 12.04 and SD: 1.8 , it suggested the correct rate on knowledge score was overall $80.28 \%$ $\left(12.04 / 15^{*} 100\right)$. Knowledge significantly differed in age, gender, marital status, education, occupation and types of the family $(\mathrm{P}<0.001)$.

Table 3 depicts that maximum participant $85.1 \%$ agree that coronavirus changed their daily routine. Only $48.4 \%$ of participants agree that infection is successfully controlled. Majority $72.6 \%$ feel that India can win the battle against novel corona. Many $76.9 \%$ of participants invest their free time in reading and watching the coronavirus news.

Figure 1 and 2 depicts that majority $58.03 \%$ of participants have a positive attitude and fewer participants i.e. $17.22 \%$ had a negative attitude towards COVID 19

\section{DISCUSSION}

In this survey majority of participants were female and welleducated, in knowledge questionnaire the researcher discovered the correct response was $80.28 \%$, which shows the majority participants had good knowledge. The more correct response from participants in COVID-19 knowledge can be because the survey was conducted after 3 months of the epidemic and the majority (75.9\%) were completed graduation. Participants actively gained knowledge about the wide- 
spread infection because, the bad situation of the epidemic, many news coverages, many information at social media and from Govt. of Odisha for public awareness.

In a recent study on knowledge, attitudes, and practices towards COVID-19 among 6910 Chinese residents found out that among the total participants, $65.7 \%$ were female, 63.5 $\%$ completed their bachelor degree or above, and there was overall $90 \%$ of correct response in the knowledge questionnaire. They also found a significant association between education and knowledge score. ${ }^{11}$ In another study with 520 participants on Knowledge, attitude and preparedness to respond to the 2019 novel coronavirus (COVID-19) among the bordered population of northern Thailand show that the most participants' age was 45.2 years, $72.9 \%$ were married, $61.5 \%$ were females and $88.4 \%$ have belonged to Thai nationality. The result reveals that $73.4 \%$ had weak knowledge, $28.5 \%$ had a poor attitude and very less $13.6 \%$ had prepared to fight against the disease. Several factors have been linked to weak knowledge like education, occupation and channel of obtaining public health information. ${ }^{12}$

The present study also reveals that $80.28 \%$ of participants scored 11-15 in knowledge questionnaire and had good knowledge of COVID 19. $15.32 \%$ of participants scored 6-10 and had average knowledge and very less i.e. only $4.4 \%$ of participants scored less than 5 and had poor knowledge. This is worth noting that maximum participants had good knowledge of the present pandemic infection. Although maximum participants had good knowledge still 58.03\% of the general population had a positive attitude towards COVID 19. This result can suggest that people may have anxiety and fear of the rapidly spreading infection. There is also a need for improving knowledge of participants by a good health education which may also improve their attitude towards COVID 19. In the present study, more than $70 \%$ of participants were well educated and female and $59.4 \%$ of participants are young adults. The health education will be more effective for people with limited access to the internet, male people, low education level, people living in rural areas and elderly people, which may increase the positive attitude towards COVID 19.

In a study conducted in Iran on 8591 participants it is revealed that $90 \%$ of respondents had better knowledge towards the disease and $60.8 \%$ of the respondents had moderate knowledge. Also, a maximum of $85 \%$ of respondents had good knowledge of the mode of transmission and highrisk groups of COVID-19. They found a significant association between female, higher age, and higher education with knowledge, attitude, and practice. ${ }^{13}$ In an online survey in India, the respondents had moderate knowledge and good knowledge on the preventive aspects. The participants had a positive attitude towards following government guidelines on COVID 19 and social distancing. The study also revealed that the participants had a high anxiety level. More than 80 $\%$ of participants were thinking of COVID-19 most of the times and $72 \%$ of participants responded that they need to use gloves and sanitizers. The study also shows that $12.5 \%$ of participants had sleep difficulties, $37.8 \%$ of participants had fear of getting the infection and $36.4 \%$ participants had distress related to social media information. ${ }^{14}$

In summary, our results revealed that Indian residents have good knowledge, a positive attitude towards the current pandemic. Particularly in females during the rapid spreading of COVID-19. Additionally, the most of participants had good knowledge but only $58.03 \%$ of participants had a positive attitude towards coronavirus infection, which suggests that a well-organized health education programs can improve COVID-19 knowledge and effective in enhancing the positive attitudes and good practices. We assume that under the joint efforts of Indian Govt. and all Indian residents, India can win the battle against COVID-19 soon.

There are some limitations in the survey such as the survey was conducted in urban residency, and the respondents are highly educated and belong to high socioeconomic. Further studies can be conducted in rural areas, with low education level and low socio-economic status to improve knowledge and attitude towards COVID 19.

\section{CONCLUSION}

The pandemic is a worldwide emergency in health and society that requires enormous strategies to limit the rapid spread of the on-going pandemic. The adherence of the general population to the control strategies is greatly influenced by their knowledge and practice towards current pandemic infection.

\section{ACKNOWLEDGEMENT}

The authors thank all the participants for their cooperation in completing the study. The authors are also grateful to authors/editors/publishers of all those articles, journals and books from where the literature for this article has been reviewed and discussed. We are extremely thankful to all the contributors who are actively participated to complete the study in this pandemic.

Conflict of Interest: None declare

Funding Statement: No fund received for this study

\section{REFERENCES}

1. Mohamed B, Nawal B. Nursing Human Factor during COVID-19 Pandemic. Int J Nurs Sci 2020;10(1): 12-24.

2. Timothy A, Karen A, Isaac A, Kangwana B, Mbushi F, Muluve 
E, et al. COVID-19-related knowledge, attitudes, and practices in urban slums in Nairobi, Kenya. Population Council, Ideas Innovations, Impact 2020;16(4):1-8.

3. Modi PD, Nair G, Uppe A. COVID-19 Awareness Among Healthcare Students and Professionals in Mumbai Metropolitan Region: A Questionnaire-Based Survey. Cureus 2020;12(4):217.

4. Michael S, Serper WM, Opsasnick L. Awareness, Attitudes, and Actions Related to COVID-19 Among Adults With Chronic Conditions at the Onset of the U.S. Outbreak A Cross-sectional Survey. Ann Inter Med 2020;9(4) :1-11.

5. Marzieh N, Bahareh E, Fatemeh N. Assessment of Iranian Nurses' Knowledge and Anxiety toward COVID-19 during the Current Outbreak in Iran. Arch Clin Infect Dis 2020 15(4):1-5.

6. https://mygov.in/covid-19/. \#IndiaFightsCoronaCOVID 19.

7. Dmitry N, Beth Ann F. Experimental Infectious Ecology: hypothesis of origin COVID-19 and its verification. Environ Epidemiol 2020;18(4):1-8.

8. Rugarabamu S, Ibrahim M, Byanaku A. Knowledge, attitude and practices(KAP) towards COVID 19: Aquick online crosssectional survey among Tanzanian residents. Preprints from medRxiv and bioRxiv. 2020. https://doi.org/10.1101/2020.04.26.2 0080820.

9. Rajib A, Mukta G, Ngo TD, , Pandey N, Patel SK, Pinchoffet $\mathrm{J}$, et al. COVID-19-related knowledge, attitudes, and practices among adolescents and young people in Bihar and Uttar Pradesh, India Study Description. Soc Behav Sci Res 2020;23(40):1-12.

10. Zhang M, Zhou M, Nie H. Knowledge, attitude and practice regarding COVID 19 among healthcare workers in Henan, China. J Hosp Infor 2020;105(2):183-187.

11. Zhong BL, Luo W, Li HM, Zhang QQ, Liu XG, Li WT, et al. Knowledge, attitudes, and practices towards COVID-19 among Chinese residents during the rapid rise period of the COVID-19 outbreak: a quick online cross-sectional survey. Int $\mathrm{J}$ Biol Sci 2020; 16(10):1745-1752.

12. Srichan P, Apidechkul B, Tawatchai TP. Knowledge, Attitude and Preparedness to Respond to the 2019 Novel Coronavirus (COVID-19) Among the Bordered Population of Northern Thailand in the Early Period of the Outbreak: A Cross-Sectional Study. WHO South East Asia J Public health 2020;9(2):118-125.

13. Erfani A, Shahriarirad R, Ranjbar K, Mirahmadizadeh A \& Moghadami M. Knowledge, Attitude and Practice toward the Novel Coronavirus (COVID-19) Outbreak: A Population-Based Survey in Iran. Preprint. Bull World Health Organ 2020;3(9):19.

14. Deblina R, Sarvodaya T. Study of knowledge, attitude, anxiety $\&$ perceived mental healthcare need in Indian population during COVID-19 pandemic. Asian J Psych 2020;51(3):1-8.

\section{Table 1: Knowledge questionnaire on COVID-19}

\begin{tabular}{|c|c|c|}
\hline SI No & Questions & Options \\
\hline & $\begin{array}{l}\text { Corona-virus transmit through droplets, touching an infected surface and further touch- } \\
\text { es face and less than the 1-meter distance from an infected person. (92.3\%) }\end{array}$ & Yes /No/ Maybe \\
\hline 2 & The symptoms of corona are hyperthermia, malaise and breathing difficulty. (89.5\%) & Yes /No/ Maybe \\
\hline 3 & The first case of novel coronavirus was identified in Wuhan (91.1\%) & Yes /No/ Maybe \\
\hline 4 & WHO announced an official name of novel coronavirus is COVn - 19 (56.8\%) & Yes /No/ Maybe \\
\hline 5 & Novel coronavirus can infect all age group (91.2\%) & Yes /No/ Maybe \\
\hline 6 & Common cold, rhinorrhoea and sneezing are not found in infected persons. (91.8\%) & Yes /No/ Maybe \\
\hline 7 & $\begin{array}{l}\text { Asymptomatic person with coronavirus infection cannot transmit the virus to others. } \\
(68.4 \%)\end{array}$ & Yes /No/ Maybe \\
\hline 8. & $\begin{array}{l}\text { Not all people with coronavirus infection will become a serious case. Only children, } \\
\text { elderly, have chronic diseases are more likely to be severe cases. }(65.6 \%)\end{array}$ & Yes /No/ Maybe \\
\hline 9. & $\begin{array}{l}\text { Currently, there is no specific treatment for novel coronavirus but by early symptomatic } \\
\text { treatment, a patient can recover. }(88.2 \%)\end{array}$ & Yes /No/ Maybe \\
\hline 10. & Pet animals can be spared the infection (6o.7\%) & Yes /No/ Maybe \\
\hline 11. & Infection can spread by mosquito \& flies. (82.6\%) & Yes /No/ Maybe \\
\hline 12. & All must wear a mask. $(86.6 \%)$ & Yes /No/ Maybe \\
\hline 13. & Isolation and treatment of infected people can reduce the spared of infection. (92.7\%) & Yes /No/ Maybe \\
\hline 14. & The coronavirus is not related to SARS/MERS (52.3\%) & Yes /No/ Maybe \\
\hline 15. & $\begin{array}{l}\text { People in contact with corona virus-infected person should keep isolated and observed } \\
\text { for 14days. }(92.2 \%)\end{array}$ & Yes /No/ Maybe \\
\hline
\end{tabular}




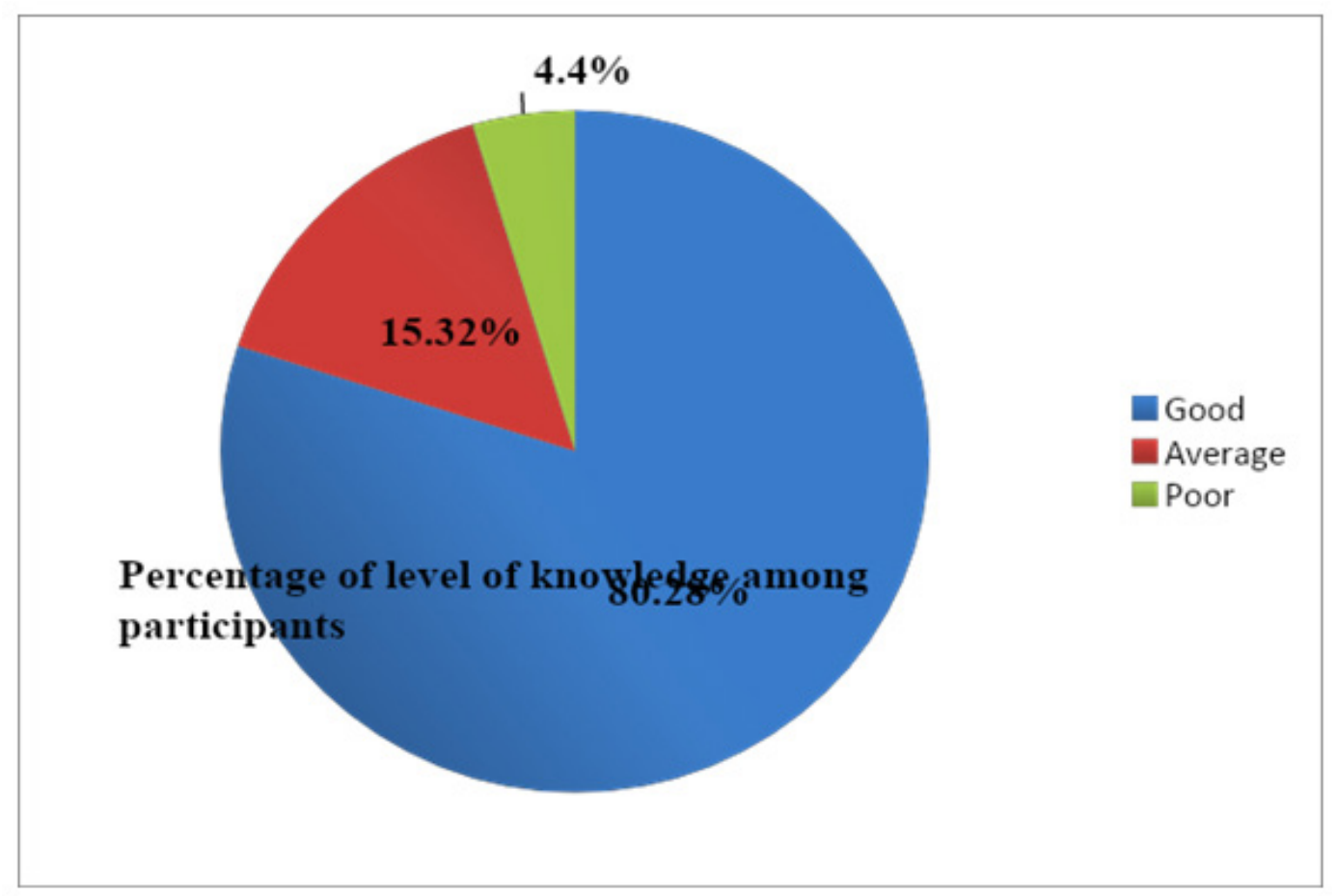

Figure 1: Level of knowledge scores on COVID 19

Table 2: Mean and SD of Knowledge by demographic data

\begin{tabular}{|c|c|c|c|c|}
\hline Demographic & & Participants (\%) & Mean \& SD & P Value \\
\hline \multirow[t]{4}{*}{ Age (years) } & $21-31$ & 19.7 & $12.5 \pm 1.2$ & \multirow{4}{*}{$<0.001$} \\
\hline & $32-42$ & 59.4 & $11.8 \pm 2.0$ & \\
\hline & $43-53$ & 14.5 & $11.6 \pm 1.9$ & \\
\hline & $54 \&$ above & 6.4 & $12.1 \pm 1.6$ & \\
\hline \multirow[t]{2}{*}{ Gender } & Male & 24.1 & $12.2 \pm 1.2$ & \multirow[t]{2}{*}{$<0.001$} \\
\hline & Female & 75.9 & $11.9 \pm 1.6$ & \\
\hline \multirow[t]{3}{*}{ Education } & Below +2 & 11.6 & $12.6 \pm 2.2$ & \multirow[t]{3}{*}{$<0.001$} \\
\hline & Graduation & 75.9 & $11.8 \pm 1.8$ & \\
\hline & Master degree $\&$ above & 12.4 & $12.3 \pm 2.1$ & \\
\hline \multirow[t]{4}{*}{ Occupation } & Students & 12.9 & $12.2 \pm 1.9$ & \multirow[t]{4}{*}{$<0.001$} \\
\hline & Unemployed & 36.5 & $11.9 \pm 2.1$ & \\
\hline & Employed & 24.9 & $12.1 \pm 1.8$ & \\
\hline & Business & 25.7 & $12.0 \pm 2.1$ & \\
\hline \multirow[t]{2}{*}{ Marital status } & Married & 76.4 & $11.9 \pm 2.2$ & \multirow[t]{2}{*}{$<0.001$} \\
\hline & Unmarried & 23.6 & $12.3 \pm 2.1$ & \\
\hline \multirow[t]{2}{*}{ Types of family } & Nuclear & 75.1 & $12.3 \pm 1.9$ & \multirow[t]{2}{*}{$<0.001$} \\
\hline & Joint & 24.9 & $12.1 \pm 2.1$ & \\
\hline
\end{tabular}


Table 3: Attitude questionnaire towards COVID 19 (response \% of participants)

\begin{tabular}{|c|c|c|c|c|}
\hline Sl no. & Questionnaire & Agree (\%) & Neutral (\%) & Disagree (\%) \\
\hline 1. & Do you think infection is successfully controlled? & 48.4 & 23.4 & 28.2 \\
\hline 2. & Do you feel India will win the battle against novel corona? & 72.6 & $17 \cdot 3$ & 10.1 \\
\hline & Do you think lockdown can slow the spread of infection? & & & \\
\hline 3. & Do you think you can be infected by novel corona virus? & $69 \cdot 3$ & 12.6 & 18.1 \\
\hline 4. & Do you think your family members are at risk? & & & \\
\hline & Do you get worried if you have common cold? & 20.2 & 36.8 & 42.9 \\
\hline 5. & Do you think corona virus changed your daily routine life? & 34.6 & 22.6 & 42.8 \\
\hline 6. & $\begin{array}{l}\text { Do you feel uncertainty about frequent modification of } \\
\text { infection control procedure? }\end{array}$ & 60.1 & 4.8 & 35.1 \\
\hline $7 \cdot$ & $\begin{array}{l}\text { Do you spend most of your time in watching information } \\
\text { related to corona virus? }\end{array}$ & 85.1 & 3.2 & 11.7 \\
\hline 8. & Do you think news about corona virus increases your anxi- & 54.2 & 18.4 & $27 \cdot 4$ \\
\hline 9. & ety? & 76.9 & 16.3 & 6.8 \\
\hline 10. & & 61.5 & 17 & 21.5 \\
\hline
\end{tabular}

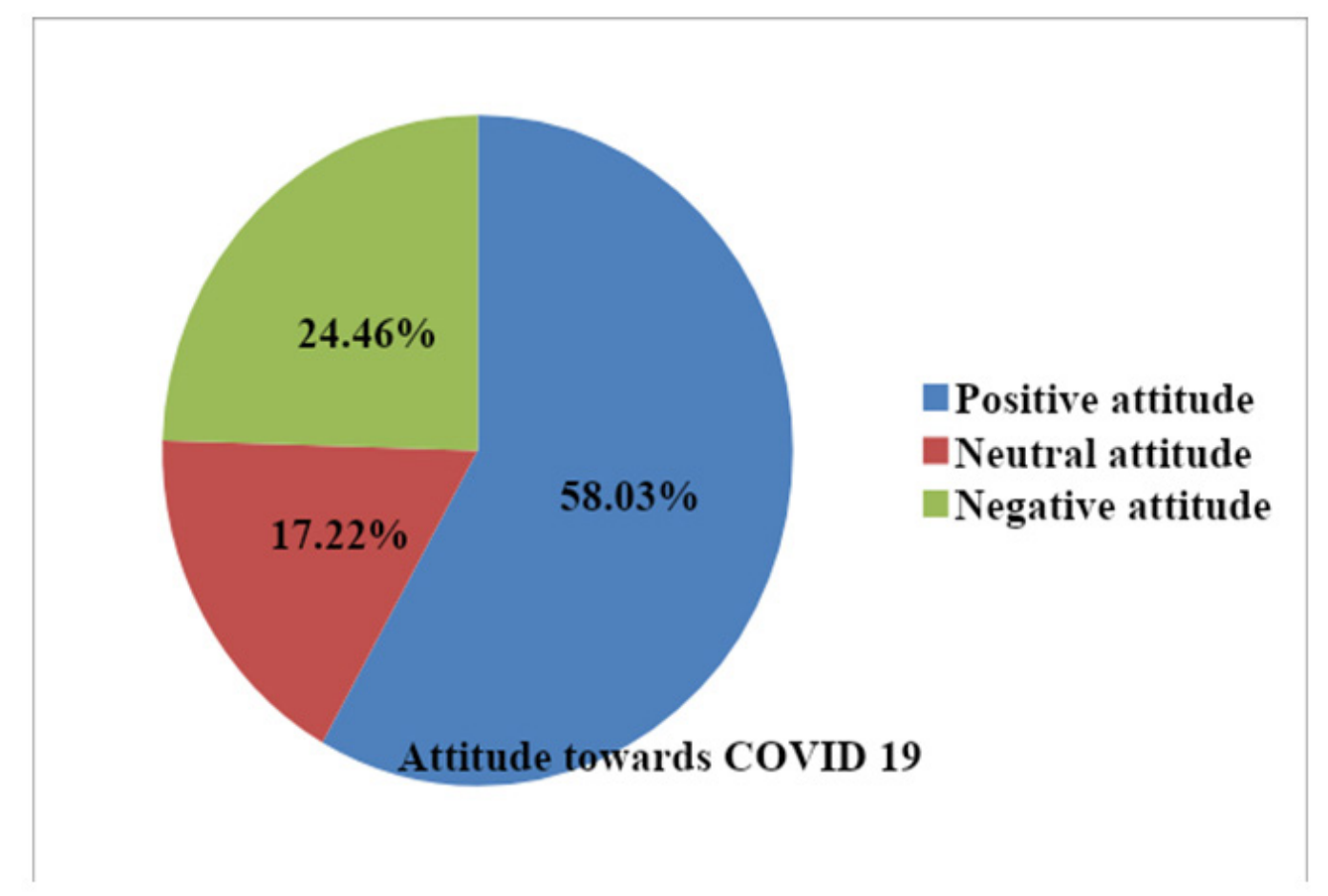

Figure 2: Level of attitude towards COVID 19. 